\title{
OCENA JAKOŚCI ŻYCIA PACJENTÓW HEMODIALIZOWANYCH Z UWZGLEDNIENIEM CZYNNIKÓW SOCJODEMOGRAFICZNYCH I MEDYCZNYCH
}

\author{
THE QUALITY OF LIFE OF HEMODIALYSIS PATIENTS ASSESSED WITH REGARD TO \\ SOCIODEMOGRAPHIC AND MEDICAL FACTORS
}

\author{
Małgorzata Starczewska ${ }^{1}$, Elżbieta Stasiak² ${ }^{2}$ Katarzyna Augustyniuk ${ }^{1}$, Daria Schneider-Matyka ${ }^{1}$, \\ Anita Rybicka ${ }^{1}$, Małgorzata Szkup ${ }^{1}$
}

\author{
${ }^{1}$ Zakład Pielegniarstwa, Pomorski Uniwersytet Medyczny w Szczecinie \\ ${ }^{2}$ Studenckie Koło Naukowe przy Zakładzie Pielęgniarstwa \\ Pomorski Uniwersytet Medyczny w Szczecinie
}

DOI: https://doi.org/10.20883/pielpol.2018.5

\begin{abstract}
STRESZCZENIE
Wstęp. Ocena jakości życia pacjentów hemodializowanych umożliwia określenie problemów wynikających z choroby przewlekłej i stosowanego leczenia w odniesieniu do aktywności człowieka w wymiarze fizycznym, psychicznym i społecznym.

Cel. Celem pracy była ocena jakości życia pacjentów hemodializowanych; uwzględniono wybrane czynniki socjodemograficzne i medyczne.

Materiał i metody. Badanie przeprowadzono w grupie 131 pacjentów Stacji Dializ Szpitala Wojewódzkiego w Gorzowie Wielkopolskim. Do badań zastosowano metodę sondażu diagnostycznego z wykorzystaniem standaryzowanego kwestionariusza SF-36 oraz autorskiego kwestionariusza ankiety.

Wyniki. Największą grupą wśród respondentów byli pacjenci oceniający swoją sytuację finansową jako średnią (50\%), czasami uczestniczący w życiu towarzyskim (56\%) i nieuprawiający sportu (71\%). Struktura chorób współistniejących u badanych wykazała, że respondenci najczęściej chorowali na nadciśnienie tętnicze (81\%), chorobę niedokrwienną serca $(34 \%)$ i cukrzycę (29\%). Wykazano istotną zależność między witalnością a wiekiem, stanem cywilnym i rodzajem pracy oraz między oceną zdrowia psychicznego a udziałem w życiu towarzyskim, pobytem w szpitalu, stanem cywilnym, paleniem papierosów oraz kondycją finansową pacjenta.

Wnioski. Wysoka pozycja społeczna, liczba hospitalizacji i czas trwania dializ mają istotny wpływ na jakość życia pacjentów hemodializowanych. Razem z dobrą sytuacją materialną oraz aktywnym uczestniczeniem w życiu towarzyskim wzrasta poziom sprawności fizycznej. Uprawianie sportu wpływa istotnie na funkcjonowanie emocjonalne chorych.
\end{abstract}

SŁOWA KLUCZOWE: jakość życia, hemodializa, pacjent.

\section{Wprowadzenie}

Badania jakości życia uwarunkowane stanem zdrowia odgrywają znaczącą rolę w naukach medycznych. Oce-

\begin{abstract}
Introduction. The assessment of the quality of life of hemodialysis patients enables us to identify their problems - resulting from a chronic disease and the treatment applied - associated with their physical, mental, and social activity.

Aim. The aim of this study was to assess the quality of life of hemodialysis patients with regard to selected sociodemographic and medical factors.

Material and methods. This survey-based study involved 131 patients of the Dialysis Center of the Provincial Hospital in Gorzów Wielkopolski. The instruments employed were a standardized questionnaire - SF-36 and the author's questionnaire.

Results. The most numerous respondents were those perceiving their financial standing as average (50\%), sometimes taking part in social life (56\%), and not going in for sports (71\%). Analysis of the respondents' concomitant diseases demonstrated that they mostly suffered from hypertension (81\%), ischemic heart disease (34\%), and diabetes (29\%). Vitality was found to be significantly related to such variables as age, marital status, and the type of job, and the mental component was related to participation in social life, stay in hospital, marital status, smoking cigarettes, and financial standing.

Conclusions. A high social status, the number of hospital stays, and duration of dialysis significantly contribute to the quality of life of hemodialysis patients. A good financial standing and active participation in social life are accompanied by a higher level of physical fitness. Going in for sports noticeably improves patients' emotional functioning.
\end{abstract}

KEYWORDS: quality of life, hemodialysis, patient.

na jakości życia pacjentów hemodializowanych umożliwia określenie problemów wynikających z choroby przewlekłej i stosowanego leczenia w odniesieniu do 
aktywności człowieka w wymiarze fizycznym, psychicznym i społecznym oraz ukazanie poglądów chorego na temat zdrowia, a także subiektywnego samopoczucia chorego [1].

W przypadku przewlekłej choroby nerek, zwłaszcza w schyłkowym jej stadium, konieczne jest leczenie nerkozastępcze, czyli dializoterapia. Wybranie najkorzystniejszej formy leczenia odbywa się w porozumieniu z chorym, z uwzględnieniem szeregu wskazań i przeciwwskazań do proponowanej metody leczenia. Dializoterapia może być przeprowadzana za pomocą dwóch metod: dializy otrzewnowej (dializy wewnątrzustrojowej) i hemodializy (dializy zewnątrzustrojowej) [2]. Hemodializa jest zabiegiem leczniczym polegającym na usuwaniu z krwi toksyn oraz ultrafiltracji wody i substancji o zbliżonej do niej masie cząsteczkowej za pomocą dializatora, tzw. sztucznej nerki [3].

Na ocenę jakości życia ogromny wpływ mają czynniki subiektywne (międzyludzkie, społeczne, emocjonalne) i obiektywne, czyli stan zdrowia, status społeczno-ekonomiczny $[4,5]$.

\section{Cel pracy}

Celem pracy była ocena jakości życia pacjentów hemodializowanych dokonana z uwzględnieniem wybranych czynników socjodemograficznych i medycznych.

\section{Materiał i metody}

Badanie przeprowadzono w grupie 131 pacjentów Stacji Dializ będącej pododdziałem Oddziału Nefrologii Wielospecjalistycznego Szpitala Wojewódzkiego w Gorzowie Wielkopolskim.

Do badań zastosowano metodę sondażu diagnostycznego z wykorzystaniem polskiej wersji standaryzowanego kwestionariusza ankiety służącego do oceny jakości życia SF-36 oraz autorskiego kwestionariusza ankiety. Kwestionariusz SF-36 składa się z 11 pytań zawierających 36 stwierdzeń, które pozwoliły określić osiem sfer jakości życia:

- funkcjonowanie fizyczne - zwyczajne czynności życia codziennego (ang. physical functioning - PF),

- $\quad$ ograniczenia w funkcjonowaniu fizycznym w życiu codziennym spowodowane stanem zdrowia fizycznego (ang. role physical - RP),

- dolegliwości bólowe i ich wpływ na codzienne funkcjonowanie (ang. bodily pain - BP),

- $\quad$ ogólne postrzeganie zdrowia - samoocena ogólnego stanu zdrowia (ang. general health - GH),

- $\quad$ witalność - poziom energii życiowej (ang. vitality - V),

- funkcjonowanie społeczne - wpływ stanu zdrowia na funkcjonowanie społeczne (ang. social functioning - SF),
- $\quad$ ograniczenia w funkcjonowaniu emocjonalnym wpływ stanu emocjonalnego na funkcjonowanie w życiu codziennym (ang. role emotional - RE),

- zdrowie psychiczne - drażliwość, impulsywność, depresja, szczęście (ang. mental health $-\mathrm{MH})[6]$.

Autorski kwestionariusz ankiety wykorzystany w pracy zawierał pytania dotyczące danych socjometrycznych oraz pytania związane z przyczynami i skutkami leczenia hemodializoterapią wykonywaną u pacjentów. Do czynników, których wpływ na jakość życia pacjentów hemodializowanych poddano ocenie, zaliczono: wiek, stan cywilny, wykształcenie, rodzaj wykonywanej pracy, sytuację finansową, uczestnictwo w życiu towarzyskim, liczbę hospitalizacji w ostatnim roku, czas trwania dializ oraz uprawianie sportu. Badania uzyskały pozytywną opinię Komisji Bioetycznej.

Do tworzenia bazy danych oraz zaprezentowania czytelnych wyników wykorzystano oprogramowanie zawarte w pakiecie Microsoft Office - arkusz kalkulacyjny Excel 2010. Hipotezy weryfikowano za pomocą statystyki $\chi^{2}$ (chi kwadrat) oraz p-value. Przyjęto poziom istotności $\alpha=0,05$. Analizy kwestionariusza oceny jakości życia SF-36 dokonano za pomocą obliczeń Statistica v. 12 pakiet zaawansowany oraz Excel 2007.

W pracy zaprezentowano tylko istotne statystycznie wyniki badań.

\section{Wyniki}

Największą grupą wśród ankietowanych byli pacjenci w wieku powyżej 65 lat - 29,8\%, niewiele mniejszy odsetek (27,5\%) to osoby w wieku 56-65 lat. Struktura płci wykazała, że większość badanych stanowili mężczyźni - 55\% respondentów. Najliczniejszą grupą badanych byli pacjenci mający wykształcenie zawodowe (42\%). Większość badanej populacji to osoby pozostające w związku małżeńskim (57\%), mieszkające w mieście powyżej 100000 ludności (50\%), nieaktywne zawodowo - przebywające na emeryturze lub rencie zdrowotnej (88\%).

Analiza sytuacji socjalnej respondentów wykazała, że $29 \%$ hemodializowanych pacjentów miało poczucie odrzucenia społecznego, co w ich mniemaniu było spowodowane chorobą. Z kolei $24 \%$ badanych utrzymywało, że nie uzyskało żadnego wsparcia ze strony jednostek opieki zdrowotnej w sytuacjach trudnych. Większość badanych osób (85\%) mieszkała z rodziną lub kimś bliskim, dzięki czemu mogła liczyć na pomoc domowników.

Największą grupą wśród respondentów byli pacjenci oceniający swoją sytuację finansową jako średnią (50\%), czasami uczestniczący w życiu towarzyskim (56\%) i nieuprawiający sportu (71\%). 
Struktura chorób współistniejących u badanych pacjentów wykazała, że respondenci najczęściej chorowali na nadciśnienie tętnicze $(81 \%)$, chorobę niedokrwienną serca (34\%) i cukrzycę (29\%).

Najczęstszą pierwotną przyczyną leczenia hemodializami, występującą u 64\% ankietowanych, była choroba nerek. Drugą przyczyną pod względem liczebności były komplikacje wynikające z wystąpienia innej choroby, które nastąpiły u 22\% respondentów. Uwarunkowania genetyczne wskazało $9 \%$ badanych, a $16 \%$ spośród badanych nie znało bezpośredniej przyczyny zastosowanego u nich leczenia nerkozastępczego.

Prawie połowa respondentów (49\%) przebywała w szpitalu 1-2 razy w ciągu ostatniego roku, a $8 \%$ badanych więcej niż 2 razy. Większość hemodializowanych (80\%) podała, że nie miała wpływu na to, jaka zostanie wybrana dla nich forma leczenia nerkozastępczego.

Największą grupę stanowili pacjenci hemodializowani w okresie poniżej 2 lat (34\% respondentów). Niewiele mniejszą - chorzy stosujący leczenie nerkozastępcze od 2 do 4 lat $-31 \%$, natomiast $27 \%$ badanej populacji stanowili pacjenci poddawani hemodializie 5-10 lat. Najmniejsza grupa to osoby dializowane ponad 10 lat (8\%).

Analiza występowania negatywnych objawów związanych z hemodializą wykazała, że największa liczba ankietowanych uskarżała się na ograniczenia dietetyczne $(78 \%)$, ponad połowa (56\%) cierpiała na zaburzenia snu, a 50\% wskazało na ból. Prawie co drugi pacjent narzekał na: złe samopoczucie (49\%), stany lękowe (47\%), występowanie zaburzeń wodno-elektrolitowych (44\%). Rzadziej występowały infekcje (15\%), nudności (20\%), zaburzenia apetytu (21\%), obniżenie nastroju (38\%). Tylko 5\% respondentów nie odczuwało żadnych dolegliwości. Pomimo wielu dokuczliwych objawów, jakie występowały u ankietowanych, wykazano, że znaczna ich część - $40 \%$ - pali papierosy.

Badania wykazały, że na witalność respondentów miały wpływ wiek, stan cywilny i rodzaj wykonywanej pracy. $Z$ danych zawartych $w$ tabeli 1 wynika, iż witalność powyżej normy prezentowali najczęściej pacjenci w wieku 36-45 lat $(63,2 \%)$, pracujący umysłowo $(64,7 \%)$ i rozwiedzeni $(71,4 \%)$. Do najmniej witalnych wśród badanych można zaliczyć osoby młode do 35 . r.ż. (100\%), pracujące fizycznie $(64,1 \%)$, będące kawalerem lub panną (78,26\%). Wykazano istotną zależność między witalnością a wiekiem $\left(\chi^{2}=11,29, p=0,045\right)$, stanem cywilnym $\left(\chi^{2}=10,28, p=0,016\right)$ i rodzajem pracy $\left(\chi^{2}=7,39, p=0,007\right)$ (Tabela 1).

Zdrowie psychiczne powyżej normy można było zaobserwować najczęściej u osób rozwiedzionych
(85,7\%), mających dobrą sytuację finansową (81,8\%), często uczestniczących w życiu towarzyskim (80\%), niehospitalizowanych $(78,6 \%)$ i niepalących papierosów (77,2\%). Zdrowie psychiczne poniżej normy prezentowali najczęściej respondenci będący kawalerem lub panną $(60,9 \%)$, o niedostatecznym uposażeniu (60\%), nieuczestniczący w życiu towarzyskim (48,7\%), hospitalizowani w ciągu ostatniego roku 1-2 razy $(42,2 \%)$ i palący papierosy $(46,1 \%)$. Stwierdzono istotną zależność między sferą psychiczną a udziałem w życiu towarzyskim $\left(\chi^{2}=6,87, p=0,032\right)$ i pobytem w szpitalu $\left(\chi^{2}=6,03\right.$, $\mathrm{p}=0,049)$. Zaobserwowano również wysoce istotną statystycznie zależność między poziomem zdrowia psychicznego a stanem cywilnym $\left(\chi^{2}=11,79, p=0,008\right)$, paleniem papierosów $\left(\chi^{2}=7,86, p=0,005\right)$ oraz bardzo istotną statystycznie zależność między zdrowiem psychicznym a kondycją finansową pacjenta $\left(\chi^{2}=14,64\right.$, $p=0,001)$ (Tabela 1).

Tabela 1. Witalność i zdrowie psychiczne pacjentów hemodializowanych w zależności od wybranych zmiennych

Table 1. Vitality and mental health of hemodialysis patients with regard to selected variables

\begin{tabular}{|c|c|c|c|c|}
\hline \multicolumn{5}{|c|}{ Witalność (V)/Vitality (V) } \\
\hline Zmienne/Variables & $\begin{array}{l}\text { Wyniki poniżej } \\
\text { normy/Results } \\
\text { lower than } \\
\text { normal } \\
(\%)\end{array}$ & $\begin{array}{c}\text { Wyniki powyżej } \\
\text { normy/Results } \\
\text { higher than normal } \\
(\%)\end{array}$ & $\chi^{2}$ & $p$ \\
\hline \multicolumn{5}{|c|}{ Wiek/Age } \\
\hline $\begin{array}{l}\text { Do } 25 \text { lat/ } \\
\text { Up to } 25 \text { years }\end{array}$ & 100,0 & 0,0 & \multirow{6}{*}{11,29} & \multirow{6}{*}{0,045} \\
\hline $\begin{array}{l}26-35 \text { lat/ } \\
26-35 \text { years }\end{array}$ & 100,0 & 0,0 & & \\
\hline $\begin{array}{l}36-45 \text { lat/ } \\
36-45 \text { years }\end{array}$ & 36,8 & 63,2 & & \\
\hline $\begin{array}{l}46-55 \text { lat/ } \\
46-55 \text { years }\end{array}$ & 59,3 & 40,7 & & \\
\hline $\begin{array}{c}56-65 \text { lat/ } \\
56-65 \text { lat years }\end{array}$ & 50,0 & 50,0 & & \\
\hline $\begin{array}{l}65 \text { lat } \mathrm{i} \text { więcej/ } \\
65 \text { years and more }\end{array}$ & 53,9 & 46,1 & & \\
\hline \multicolumn{5}{|c|}{ Stan cywilny/Marital status } \\
\hline $\begin{array}{l}\text { Kawaler/panna/ } \\
\text { Single }\end{array}$ & 78,3 & 21,7 & \multirow{4}{*}{10,28} & \multirow{4}{*}{0,016} \\
\hline $\begin{array}{l}\text { Żonaty/mężatka/ } \\
\text { Married }\end{array}$ & 56,0 & 44,0 & & \\
\hline $\begin{array}{l}\text { Wdowiec/wdowa/ } \\
\text { Widowed }\end{array}$ & 42,1 & 57,9 & & \\
\hline $\begin{array}{l}\text { Rozwiedziony/roz- } \\
\text { wiedziona/Divorced }\end{array}$ & 28,6 & 71,4 & & \\
\hline \multicolumn{5}{|c|}{$\begin{array}{c}\text { Rodzaj pracy wśród osób aktywnych zawodowo/ } \\
\text { The type of work of those employed }\end{array}$} \\
\hline Fizyczna/Physical & 64,1 & 35,9 & \multirow{2}{*}{7,39} & \multirow{2}{*}{0,007} \\
\hline Umysłowa/Mental & 35,3 & 64,7 & & \\
\hline
\end{tabular}




\begin{tabular}{|c|c|c|c|c|}
\hline \multicolumn{5}{|c|}{ Zdrowie psychiczne (MH)/Mental health (MH) } \\
\hline \multicolumn{5}{|c|}{ Stan cywilny/Marital status } \\
\hline $\begin{array}{l}\text { Kawaler/panna/ } \\
\text { Single }\end{array}$ & 60,9 & 39,1 & \multirow{4}{*}{11,79} & \multirow{4}{*}{0,008} \\
\hline $\begin{array}{c}\text { Żonaty/mężatka/ } \\
\text { Married }\end{array}$ & 26,7 & 73,3 & & \\
\hline $\begin{array}{c}\text { Wdowiec/wdowa/ } \\
\text { Widowed }\end{array}$ & 31,6 & 68,4 & & \\
\hline $\begin{array}{l}\text { Rozwiedziony/roz- } \\
\text { wiedziona/Divorced }\end{array}$ & 14,3 & 85,7 & & \\
\hline \multicolumn{5}{|c|}{ Sytuacja finansowa/Financial standing } \\
\hline Dobra/Good & 18,2 & 81,8 & \multirow{3}{*}{14,64} & \multirow{3}{*}{0,001} \\
\hline Średnia/Average & 26,5 & 73,5 & & \\
\hline Niedostateczna/Poor & 60,0 & 40,0 & & \\
\hline \multicolumn{5}{|c|}{ Uczestnictwo w życiu towarzyskim/Participation in social life } \\
\hline Często/Often & 20,0 & 80,0 & \multirow{3}{*}{6,87} & \multirow{3}{*}{0,032} \\
\hline Czasami/Sometimes & 27,0 & 73,0 & & \\
\hline $\begin{array}{l}\text { Nie uczestniczę/ } \\
\text { Don't participate }\end{array}$ & 48,7 & 51,3 & & \\
\hline \multicolumn{5}{|c|}{ Hospitalizacja/Hospitalization } \\
\hline Wcale/No & 21,4 & 78,6 & \multirow{3}{*}{6,03} & \multirow{3}{*}{0,049} \\
\hline $1-2$ razy/1-2 times & 42,2 & 57,8 & & \\
\hline $\begin{array}{l}\text { Więcej niż } 3 \text { razy/ } \\
\text { More than } 3 \text { times }\end{array}$ & 27,3 & 72,7 & & \\
\hline \multicolumn{5}{|c|}{ Palenie papierosów/Smoking } \\
\hline Tak/Yes & 46,1 & 53,9 & \multirow{2}{*}{7,86} & \multirow{2}{*}{0,005} \\
\hline Nie/No & 22,8 & 77,2 & & \\
\hline
\end{tabular}

$\chi^{2}$ - test chi kwadrat (Pearsona)/Pearson's chi-square test, $\mathrm{p}$ - poziom istotności wyznaczony dla $\chi^{2} /$ the level of significance for $\chi^{2}$

Źródło: opracowanie własne

Source: author's own analysis

Wyniki powyżej normy dotyczące funkcjonowania społecznego respondentów można było najczęściej zaobserwować u pacjentów z wykształceniem wyższym (100\%), będących w dobrej sytuacji finansowej (84,9\%), poddawanych dializie od 2 do 4 lat $(85,4 \%)$ i hospitalizowanych w ciągu ostatniego roku ponad 3 razy $(90,9 \%)$. Poniżej normy uzyskały wynik osoby z wykształceniem podstawowym (50\%), mające niedostateczne dochody $(46,7 \%)$, dializowane poniżej 2 lat $(43,2 \%)$ i hospitalizowane od 1 do 2 razy w ciągu ostatniego roku $(39,1 \%)$. Wykazano istotną zależność między funkcjonowaniem społecznym a wykształceniem $\left(\chi^{2}=10,63, p=0,013\right)$, sytuacją finansową ( $\left.\chi^{2}=7,65, p=0,022\right)$, czasem trwania dializ $\left(\chi^{2}=8,87, p=0,031\right)$ i liczbą hospitalizacji $\left(\chi^{2}=6,82, p=0,033\right)$ (Tabela 2).

Ogólne postrzeganie zdrowia powyżej normy najczęściej prezentowały osoby będące $w$ dobrej sytuacji finansowej $(78,8 \%)$, dializowane od 2 do 4 lat $(73,2 \%)$, hospitalizowane $w$ związku ze stanem swojego zdrowia powyżej 3 razy w ciągu ostatniego roku $(63,6 \%)$. Swoją kondycję zdrowotną jako poniżej normy określali respondenci niedostatecznie sytuowani materialnie $(50 \%)$, poddający się dializie ponad 10 lat $(81,8 \%)$ i hospitalizowani $1-2$ razy w ciągu ostatniego roku $(54,7 \%)$.
Stwierdzono istotną zależność między ogólnym postrzeganiem zdrowia a sytuacją finansową $\left(\chi^{2}=6,06\right.$, $p=0,048)$ oraz liczbą hospitalizacji $\left(\chi^{2}=6,42, p=0,040\right)$ i wysoce istotną zależność między postrzeganiem zdrowia a czasem trwania dializ $\left(\chi^{2}=14,10, p=0,003\right)$ (Tabela 2).

Tabela 2. Funkcjonowanie społeczne i ogólne postrzeganie zdrowia ankietowanych w zależności od wybranych zmiennych Table 2. Social functioning and general health of the surveyed with regard to selected variables

\begin{tabular}{|c|c|c|c|c|}
\hline \multicolumn{5}{|c|}{ Funkcjonowanie społeczne (SF)/Social functioning (SF) } \\
\hline Zmienne/Variables & $\begin{array}{l}\text { Wyniki poniżej } \\
\text { normy/Results } \\
\text { lower than } \\
\text { normal } \\
(\%)\end{array}$ & $\begin{array}{c}\text { Wyniki } \\
\text { powyżej } \\
\text { normy/Results } \\
\text { higher than } \\
\text { normal } \\
(\%)\end{array}$ & $\chi^{2}$ & $\mathrm{p}$ \\
\hline \multicolumn{5}{|c|}{ Wykształcenie/Education } \\
\hline Podstawowe/Primary & 50,0 & 50,0 & \multirow{4}{*}{10,63} & \multirow{4}{*}{0,013} \\
\hline Zawodowe/Vocational & 29,1 & 70,9 & & \\
\hline Średnie/Secondary & 32,6 & 67,4 & & \\
\hline Wyższe/Higher & 0,0 & 100,0 & & \\
\hline \multicolumn{5}{|c|}{ Sytuacja finansowa/Financial standing } \\
\hline Dobra/Good & 15,1 & 84,9 & \multirow{3}{*}{7,65} & \multirow{3}{*}{0,022} \\
\hline Średnia/Average & 27,9 & 72,1 & & \\
\hline Niedostateczna/Poor & 46,7 & 53,3 & & \\
\hline \multicolumn{5}{|c|}{ Czas trwania dializ/Duration of dialysis } \\
\hline Poniżej 2 lat/Less than 2 years & 43,2 & 56,8 & \multirow{4}{*}{8,87} & \multirow{4}{*}{0,031} \\
\hline 2-4 lata/2-4 years & 14,6 & 85,4 & & \\
\hline $5-10$ lat $/ 5-10$ years & 25,7 & 74,3 & & \\
\hline $\begin{array}{c}\text { Powyżej } 10 \text { lat/More than } \\
10 \text { years }\end{array}$ & 36,4 & 63,6 & & \\
\hline \multicolumn{5}{|c|}{ Hospitalizacja/Hospitalization } \\
\hline Wcale/No & 21,4 & 78,6 & \multirow{3}{*}{6,82} & \multirow{3}{*}{0,033} \\
\hline 1-2 razy/1-2 times & 39,1 & 60,9 & & \\
\hline $\begin{array}{c}\text { Więcej niż } 3 \text { razy/More than } \\
3 \text { times }\end{array}$ & 9,1 & 90,9 & & \\
\hline \multicolumn{5}{|c|}{ Ogólne postrzeganie zdrowia (GH)/General health (GH) } \\
\hline \multicolumn{5}{|c|}{ Sytuacja finansowa/Financial standing } \\
\hline Dobra/Good & 21,2 & 78,8 & \multirow{3}{*}{6,06} & \multirow{3}{*}{0,048} \\
\hline Średnia/Average & 41,2 & 58,8 & & \\
\hline Niedostateczna/Poor & 50,0 & 50,0 & & \\
\hline \multicolumn{5}{|c|}{ Czas trwania dializ/Duration of dialysis } \\
\hline Poniżej 2 lat/Less than 2 years & 29,6 & 70,4 & \multirow{4}{*}{14,10} & \multirow{4}{*}{0,003} \\
\hline 2-4 lata/2-4 years & 26,8 & 73,2 & & \\
\hline $5-10$ lat $/ 5-10$ years & 48,6 & 51,4 & & \\
\hline $\begin{array}{c}\text { Powyżej } 10 \text { lat/More than } \\
10 \text { years }\end{array}$ & 81,8 & 18,2 & & \\
\hline \multicolumn{5}{|c|}{ Hospitalizacja/Hospitalization } \\
\hline Wcale/No & 32,1 & 67,9 & \multirow{3}{*}{6,42} & \multirow{3}{*}{0,040} \\
\hline $1-2$ razy/1-2 times & 54,7 & 45,3 & & \\
\hline $\begin{array}{c}\text { Więcej niż } 3 \text { razy/More than } \\
3 \text { times }\end{array}$ & 36,4 & 63,6 & & \\
\hline
\end{tabular}

$\chi^{2}$ - test chi kwadrat (Pearsona)/Pearson's chi-square test, $\mathrm{p}$ - poziom istotności wyznaczony dla $\chi^{2} /$ the level of significance for $\chi^{2}$

Źródło: opracowanie własne

Source: author's own analysis 
Funkcjonowanie fizyczne ankietowanych okazało się istotnie zależne od sytuacji finansowej $\left(\chi^{2}=6,27\right.$, $p=0,043)$ i stopnia uczestnictwa w życiu towarzyskim $\left(\chi^{2}=6,36, p=0,041\right)$. Aktywni fizycznie powyżej normy okazali się respondenci dobrze sytuowani finansowo (54,5\%) i często uczestniczący w życiu towarzyskim (70\%). Fizycznie poniżej normy funkcjonowali pacjenci niedostatecznie zarabiający $(73,3 \%)$, stroniący od kontaktów towarzyskich $(64,86 \%)$ (Tabela 3).

Tabela 3. Funkcjonowanie fizyczne respondentów w zależności od sytuacji finansowej i uczestnictwa w życiu towarzyskim

Table 3. Physical functioning with regard to financial standing and participation in social life

\begin{tabular}{ccccc}
\hline \multicolumn{5}{c}{ Funkcjonowanie fizyczne (PF)/Physical functioning (PF) } \\
\hline Zmienne/Variables & $\begin{array}{c}\text { Wyniki poniżej } \\
\text { normy/Results } \\
\text { lower than } \\
\text { normal (\%) }\end{array}$ & $\begin{array}{c}\text { Wyniki } \\
\text { powyżej } \\
\text { normy/Results } \\
\text { higher than } \\
\text { normal (\%) }\end{array}$ & $\chi^{2}$ & $\mathrm{p}$ \\
Sytuacja finansowa/Financial standing & \\
Dobra/Good & 45,5 & 54,5 & & \\
Średnia/Average & 48,5 & 51,5 & 6,27 & 0,043 \\
Niedostateczna/Poor & 73,3 & 26,7 & & \\
Uczestnictwo w życiu towarzyskim/Participation in social life & \\
Często/Often & 30,0 & 70,0 & & \\
Czasami/Sometimes & 54,1 & 45,9 & 6,36 & 0,041 \\
Nie uczestniczę/Don't & 64,9 & 35,1 & & \\
participate & &
\end{tabular}

$\chi^{2}$ - test chi kwadrat (Pearsona)/Pearson's chi-square test, $\mathrm{p}$ - poziom istotności wyznaczony dla $\chi^{2} /$ the level of significance for $\chi^{2}$

Źródło: opracowanie własne

Source: author's own analysis

Analiza zgromadzonych danych wykazała istotną statystycznie zależność między emocjonalnym funkcjonowaniem pacjentów hemodializowanych a uprawianiem sportu $\left(\chi^{2}=8,42, p=0,038\right)$. Okazało się, że najczęściej wyniki powyżej normy uzyskiwali ankietowani często uprawiający sport (100\%), poniżej - ci, którzy go nie uprawiają, gdyż nie mają na to ochoty $(46,8 \%)$ (Tabela 4).

\section{Dyskusja}

Ocena jakości życia pacjentów hemodializowanych to podstawa poznania przekroju problemów, z jakimi zmagają się osoby leczone z powodu przewlekłej niewydolności nerek. Dzięki niej można poznać subiektywne odczucia pacjentów związane z chorobą i jej oddziaływanie na funkcjonowanie zarówno w domu, jak i poza nim [7].

Przewlekła choroba nerek nie dotyczy tylko jednego układu narządów, gdyż powoduje pogorszenie stanu ogólnego pacjenta. Zgodnie z badaniami przeprowadzonymi przez Plutę i wsp. przewlekle dializowani pa- cjenci zapadają na schorzenia nerkowo-naczyniowe, spowodowane przyspieszonym postępem miażdżycy, skutkujące pojawieniem się choroby niedokrwiennej serca, przerostem lewej komory i zaburzeniem funkcji mięśnia sercowego: pojawiają się niewydolność serca, zaburzenia rytmu [8]. Wnioski te pokrywają się z wynikami badań autorskich, w których jako jedną z najczęściej występujących chorób współistniejących wykazano chorobę niedokrwienną serca.

Tabela 4. Funkcjonowanie emocjonalne w badanej grupie w zależności od częstotliwości uprawiania sportu

Table 4. Emotional functioning with regard to the participation in sport activities

\begin{tabular}{|c|c|c|c|c|}
\hline \multicolumn{5}{|c|}{ Ograniczenia w funkcjonowaniu emocjonalnym (RE)/Role emotional (RE) } \\
\hline Zmienne/Variables & $\begin{array}{c}\text { Wyniki } \\
\text { poniżej } \\
\text { normy/Re- } \\
\text { sults lower } \\
\text { than normal } \\
(\%)\end{array}$ & $\begin{array}{c}\text { Wyniki } \\
\text { powyżej } \\
\text { normy/Re- } \\
\text { sults higher } \\
\text { than normal } \\
(\%)\end{array}$ & $\chi^{2}$ & $p$ \\
\hline \multicolumn{5}{|c|}{ Uprawianie sportu/Going in for sports } \\
\hline $\begin{array}{c}\text { Tak, systematycznie/ } \\
\text { Yes, regularly }\end{array}$ & 0,0 & 100,0 & \multirow{4}{*}{8,42} & \multirow{4}{*}{0,038} \\
\hline $\begin{array}{l}\text { Od czasu do czasu/ } \\
\text { From time to time }\end{array}$ & 19,4 & 80,6 & & \\
\hline $\begin{array}{l}\text { Nie, nie chce/ } \\
\text { No, I don't want }\end{array}$ & 46,8 & 53,2 & & \\
\hline $\begin{array}{l}\text { Nie, nie wolno mi/ } \\
\text { No, I mustn't }\end{array}$ & 33,3 & 66,7 & & \\
\hline
\end{tabular}

$\chi^{2}$ - test chi kwadrat (Pearsona)/Pearson's chi-square test, $\mathrm{p}$ - poziom istotności wyznaczony dla $\chi^{2} /$ the level of significance for $\chi^{2}$

Źródło: opracowanie własne

Source: author's own analysis

Częstotliwość występowania chorób, których leczenie wymaga hemodializoterapii, wzrasta z wiekiem. Odsetek osób w Polsce, które ukończyły 65. rok życia, na dzień 31 grudnia 2013 r. wynosił 14,7\%. Prognozuje się, że w 2020 r. będzie to 18,9\%, a 15 lat później - 24,5\% [9]. W badaniach Grochans i wsp. [10] wykazano, że znaczna część pacjentów hemodializowanych - 32,5\% - miała ponad 65 lat. Potwierdzają to analizy badań własnych - w badanej populacji 29,8\% ankietowanych ukończyło 65 lat.

Hemodializie poddawani są chorzy z ostrą i przewlekłą chorobą nerek w zaawansowanym stadium. Konieczność stosowania tego zabiegu skutkuje wieloma dokuczliwymi objawami. W badaniach Bojanowskiej i wsp. [11] wykazano, że $62 \%$ ankietowanych stwierdziło, że z zabiegami hemodializy wiąże się występowanie wielu problemów, które pojawiają się w trakcie dializ lub pozabiegu. Z wykonanych przez Zielińską-Więczkowską i wsp. [12] badań na 1215 osobach wynika, że problemami tymi są najczęściej: wahania ciśnienia tętniczego (40\% badanych), bóle głowy (12,5\%), świąd skóry (12,5\%), 
ogólne osłabienie (11,3\%), ból (7,5\%). Pacjenci borykali się z trudnościami w chodzeniu, niepokoił ich wygląd kończyny z przetoką naczyniową oraz obrzęki. Ankietowani jako szczególnie uciążliwy problem wskazywali trudności ze snem, ograniczenia dietetyczne - głównie płynowe (74,3\%), ograniczenia czasowe (7,6\%). Chorzy w związku z zabiegami dializy czuli się zupełnie $(46,2 \%)$ lub częściowo (35\%) wyczerpani fizycznie. Wyniki te w wielu punktach pokrywają się z rezultatami przedstawionymi w pracy.

Rakowicz i wsp. [13] zwracają uwagę na fakt istnienia dodatniej korelacji pomiędzy jakością życia starszych pacjentów leczonych powtarzalnymi zabiegami hemodializ a ich funkcjonowaniem na poziomie emocjonalnym ( $r=0,3648 ; p<0,05)$. Nie stwierdzono takiej korelacji w autorskich badaniach, natomiast zaobserwowano związek między czasem trwania hemodializ a ogólnym postrzeganiem zdrowia $(p=0,003)$ oraz funkcjonowaniem społecznym ( $p=0,031)$. Giętek i wsp. [14] zauważają, że długość okresu hemodializoterapii ma zasadniczy wpływ na funkcjonowanie pacjentów w sferze fizycznej i społecznej. Pacjenci hemodializowani, którzy są aktywni zawodowo, będący w dobrej sytuacji finansowej radzą sobie z negatywnymi objawami, zwłaszcza w sferze emocjonalnej, dużo lepiej niż ci, którzy nie pracują [15]. Powyższe doniesienia pokrywają się z analizami przedstawionymi w pracy.

Podkreśla się korzystny wpływ ćwiczeń fizycznych na prawidłowe funkcjonowanie wielu układów i narządów, zwłaszcza u osób w starszym wieku. Uważa się, że regularny trening fizyczny korzystnie wpływa na wydolność sercowo-naczyniową [16]. Z badań Chojak-Fijałki i wsp. [17] wynika, że kilka miesięcy odpowiednio dostosowanego programu treningowego spowodowało istotną poprawę wydolności fizycznej pacjentów hemodializowanych. Wykazano, że w okresie trwania dializoterapii prowadzenie ćwiczeń fizycznych przy użyciu cykloergometru rowerowego jest nie tylko możliwe, ale i bezpieczne. Hemodializoterapia jest ograniczeniem dla wielu pacjentów, zwłaszcza dla pacjentów w starszym wieku, nie wyklucza ona jednak możliwości podejmowania aktywności sportowej. W badaniach Kapki-Skrzypczak i wsp. [18] wykazano, że wśród pacjentów hemodializowanych aktywne uprawianie sportu deklarowało tylko 23,3\% chorych. Wyniki własne były podobne i pokazały, iż 29\% respondentów uprawiało sport.

W badaniach Wojczyk [19] wykazano, iż pacjenci chorujący przewlekle, wymagający hemodializoterapii, zauważyli u siebie negatywny wpływ, jaki ma ich sytuacja, na liczbę i jakość kontaktów towarzyskich. Co trzeci badany pacjent rzadziej spotykał się ze znajomymi, a 20\% ankietowanych najchętniej spędzało czas w domu. W dużym stopniu pokrywa się to z wynika- mi badań, które przedstawiono w niniejszej pracy. Wykazano, że 15\% respondentów często uczestniczyło w życiu towarzyskim, czasami - 56\%, natomiast $28 \%$ nie uczestniczyło w spotkaniach ze znajomymi. Zaniechanie kontaktów towarzyskich często skutkuje wystąpieniem depresji, która pojawia się u 50\% pacjentów leczonych nerkozastępczo. Zgodnie z analizami Trafidło [20] zaburzenia depresyjne współistnieją najczęściej z zaburzeniami lękowymi, które pogarszają jakość życia i negatywnie wpływają na współpracę chorego z zespołem terapeutycznym.

Większość pacjentów zdaje sobie sprawę ze szkodliwości palenia tytoniu, jednak $\mathrm{w}$ badanej grupie stwierdzono, że 40\% respondentów pali papierosy. Taki sam wynik uzyskali Gniadek i wsp. [21], badający zachowania zdrowotne chorych przewlekle poddawanych zabiegom hemodializy. Kuźmicka i wsp. [22] w swojej pracy zwracają uwagę na to, że palenie papierosów nie wpływa na jakość życia w sposób bezpośredni i jednoznaczny. Jednak w większości analiz osoby niepalące wyżej oceniały swoją jakość życia niż te, które palą. Respondenci, którzy rzucili palenie, także podkreślali większą satysfakcję z życia [22].

\section{Wnioski}

1. Wysoka pozycja społeczna związana z wykonywaniem pracy umysłowej, wyższym wykształceniem, dobrą sytuacją finansową korzystnie wpływa na odczuwanie pozytywnej jakości życia przez pacjentów hemodializowanych.

2. Razem z dobrą sytuacją materialną oraz aktywnym uczestniczeniem w życiu towarzyskim wzrasta poziom sprawności fizycznej.

3. Liczba hospitalizacji i czas trwania dializ mają istotny wpływ na jakość życia pacjentów poddanych hemodializie.

4. Uprawianie sportu wpływa istotnie na funkcjonowanie emocjonalne chorych hemodializowanych.

\section{Piśmiennictwo}

1. Szyguła-Jurkiewicz B, Kowalska M, Mościński M. Jakość życia jako element oceny stanu zdrowia i efektywności leczenia chorych ze schorzeniami układu sercowo-naczyniowego. Folia Cardiol. 2011; 6(1): 62-71.

2. Dutkowska D, Rumianowski B, Grochans E, Karakiewicz B, Laszczyńska M. Porównanie jakości życia pacjentów hemodializowanych i dializowanych otrzewnowo. Probl Hig Epidemiol. 2012; 93(3): 529-535.

3. Zdrojewski Z. Techniki stosowane w hemodializie. W: Rutkowski B (red.) Dializoterapia w codziennej praktyce. Gdańsk: Wydawnictwo Medyczne MAKmed; 1996. 76-87.

4. Wnuk M, Marcinkowski JT, Jakość życia w chorobach przewlekłych. Hygeia Public Health. 2013; 48(3): 274-278.

5. Kapka-Skrzypczak L, Lipin B, Niedźwiedzka J, Sawicki K, Cyranka M, Haratym-Maj A, Skrzypczak M, Kruszewski M. Subiektywna ocena jakości życia pacjentów dializowanych 
metodą dializy otrzewnowej oraz hemodializy. Probl Hig Epidemiol. 2012; 93(4): 791-796.

6. Tylka J, Piotrowicz R. Kwestionariusz oceny jakości życia SF-36 - wersja polska. Kardiol Pol. 2009; 67: 1166-1169.

7. Kukielczak A. Rozwój zainteresowania w naukach medycznych badaniami nad jakością życia. Prz Epidemiol. 2012; 66: 539-545.

8. Pluta A, Felsmann A, Faleńczyk K, Wybrane problemy zdrowotne w populacji pacjentów dializowanych oraz udział pielęgniarki w ich rozwiązywaniu. Med Rodz. 2014; 3: 128-132.

9. Prognoza ludności na lata 2014-2050. Warszawa: Główny Urząd Statystyczny; 2014, http://stat.gov.pl/files/gfx/portalinformacyjny/pl/defaultaktualnosci/5469/1/5/1/prognoza_ludnosci_na_lata_2014_-_2050.pdf (data dostępu: 25.11.2016).

10. Grochans E, Sawko W, Pawlik J, Jurczak A, Stanisławska M, Mroczek B. Ocena jakości życia pacjentów hemodializowanych. Fam Med Primary Care Rev. 2012; 14(3): 366-369.

11. Bojanowska M, Hreńczuk M, Jonas M, Małkowski P. Leczenie hemodializami a przeszczepienie nerki w opinii pacjentów oczekujących na transplantację. Piel Pol. 2015; 3(57): 278-282.

12. Zielińska-Więczkowska H, Krokowska B. Ocena jakości życia chorych dializowanych. Med Rodz. 2014; 2: 42-45.

13. Rakowicz E, Wieczorowska-Tobis K, Talarska D. Jakość życia starszych pacjentów leczonych hemodializami. Geriatria. 2007; 1: 1-7.

14. Giętek M, Czech N, Białek-Dratwa A, Fizia K, Muc-Wierzgoń M, Kokot T, Nowakowska-Zajdel E. Jakość życia chorych poddawanych przewlekle leczeniu nerkozastępczemu przegląd piśmiennictwa. Hygeia Public Health. 2012; 47(2): 151-156.

15. Dutkowska D, Rumianowski B, Grochans E, Karakiewicz B, Leszczyńska M. Porównanie jakości życia pacjentów hemodializowanych i dializowanych otrzewnowo. Probl Hig Epidemiol. 2012; 93(3): 529-535.
16. Gębka D, Kędziora-Kornatowska K. Korzyści z treningu zdrowotnego u osób w starszym wieku. Probl Hig Epidemiol. 2012; 93(2): 256-259.

17. Chojak-Fijałka K, Smoleński O. Rehabilitacja ruchowa chorych przewlekle dializowanych - wyniki badań własnych. Probl Lek. 2006; 45(3): 247-256.

18. Kapka-Skrzypczak L, Lipin B, Niedźwiecka J, Sawicki K, Cyranka M, Haratym-Maj A, Skrzypczak M, Kruszewski M. Subiektywna ocena jakości życia pacjentów dializowanych metodą dializy otrzewnowej oraz hemodializy. Probl Hig Epidemiol 2012; 93(4): 790-797.

19. Wojczyk A. Problemy codziennego życia hemodializowanych pacjentów. Piel Zdr Publ. 2014; 4(2): 143-148.

20. Trafidło E. Depresja u chorych dializowanych. Dializa i Ty. 2011; 1(12): 15.

21. Gniadek A, Bodys-Cupak I, Poskróbek A. Zachowania ryzykowne oraz prozdrowotne wśród pacjentów poddanych hemodializie. Probl Piel. 2015; 23(4): 452-457.

22. Kuźmicka P, Jasińska M, Grzegorczyk M, Karakiewicz B. Palenie tytoniu a jakość życia. Med Środow. 2013, 16(1): 43-50.

Artykuł przyjęty do redakcji: 26.04.2017

Artykuł przyjęty do publikacji: 11.07.2017

Źródło finansowania: Praca nie jest finansowana z żadnego źródła. Konflikt interesów: Autorzy deklarują brak konfliktu interesów.

Adres do korespondencji:
Małgorzata Starczewska
ul. Żołnierska 48
$71-210$ Szczecin
tel.: 914800910
e-mail: mlary@pum.edu.pl
Zakład Pielęgniarstwa
Pomorski Uniwersytet Medyczny w Szczecinie

